\title{
Erratum to: Natalie Klein: Maritime security and the law of the sea
}

\section{Oxford University Press, Great Clarendon Street, Oxford OX2 6DP, UK, 2011, ISBN: 978-0-19-956653-2, pp. xxvi/350, Hardcover GBP 70}

\section{Maximo Q. Mejia Jr.}

Published online: 26 May 2012

(C) World Maritime University 2012

\section{Erratum to: WMU J Marit Affairs \\ DOI 10.1007/s13437-012-0028-z}

The title supplied for this Book Review, was incorrect, since Ms Klein was not the editor of the reviewed publication but the author.

The correct title should therefore be:

Natalie Klein: Maritime security and the law of the sea

Oxford University Press, Great Clarendon Street, Oxford OX2 6DP, UK, 2011, ISBN: 978-0-19-956653-2, pp. xxvi/350, Hardcover GBP 70

This mistake happened during the production process of the article and unfortunately remained unnoticed.

The publisher apologises for this mistake.

The online version of the original article can be found at http://dx.doi.org/10.1007/s13437-012-0028-z.

M. Q. Mejia Jr. $(\bowtie)$

World Maritime University, P.O. Box 500, S-201 24 Malmö, Sweden

e-mail: mm@wmu.se 